\title{
A Comparative List of Fern Pinna-traces, with some Notes on the Leaf-trace in the Ferns.
}

BY

\author{
R. C. DAVIE, M.A., D.Sc., \\ Lecturer in Botany in the University of Edinburgh.
}

With five Figures in the Text.

$\mathrm{T}$ three papers dealing with the anatomy of Fern-leaves ${ }^{1}$ the contrast between the 'marginal' and 'extra-marginal' types of pinna-supply from the vascular system of the rachis has been emphasized. The contrast is not perfectly sharp and well defined-in one or two Ferns it is difficult to decide whether the type of pinna-supply is marginal or extra-marginal, for some forms of the extra-marginal type come very close to the marginal. But on the whole it can be said that the same type appears in the species of a genus; that the marginal type is found among the more primitive Ferns in the evolutionary scale and among the most advanced genera; that the extra-marginal type occurs in those Ferns which stand midway in the system of classification and in some advanced forms.

Since the list summarizing the results of investigation up to $1914^{2}$ was published, many Fern-leaves have been examined. The accompanying table shows the full number of species and includes those already mentioned. Every available genus containing members with pinnate leaves has been investigated. For several critical genera additional species have been studied. The list summarizes the result of the examination of 90 genera and 220 species of Ferns. Fifty-one genera with 126 species have the marginal type of pinna-supply; 46 genera with 94 species have the extramarginal type. The overlap in the numbers of genera is due to the occurrence of both types of pinna-supply in certain genera, viz. Balantium, Leptochilus, Microlepia, Odontosoria, Coniogramme, Notholaena, and Onychium.

The width of the field which I have been able to cover is due to the kindness of the Regius Keeper of the Royal Botanic Garden, Edinburgh,

1 The Structure and Affinities of Peranema and Diacalpe, Ann. of Bot., vol. xxvi, pp. 245-68; The Pinna-trace in the Ferns, Trans. Roy. Soc. Edin., vol. 1, pp. 349-78; On the Leaf-trace in some Pinnate Leaves, ibid., vol. lii, pp. $1-36$.

2 Trans. Roy. Soc, Edin., vol. 1, pp. 349-78.

[Annals of Botany, Vo1. XXXII. No. CXXVI. April, 1918.] 


\section{Davie.-Comparative List of Fern Pinna-traces, with}

who has given me free access to the rich collections under his charge. To him and to Professor F. O. Bower, F.R.S., who kindly supplied me with material of several important species, I desire to express my thanks.

In the present list I have been able to group the forms of pinna-supply under two heads. In my last paper ${ }^{1}$ I was unable definitely to state that there are only the two types. These two types of pinna-supply differ only in regard to their derivation from the adaxial portion of the leaf-trace; if the portion (or all) of the pinna-trace derived from the adaxial portion of the
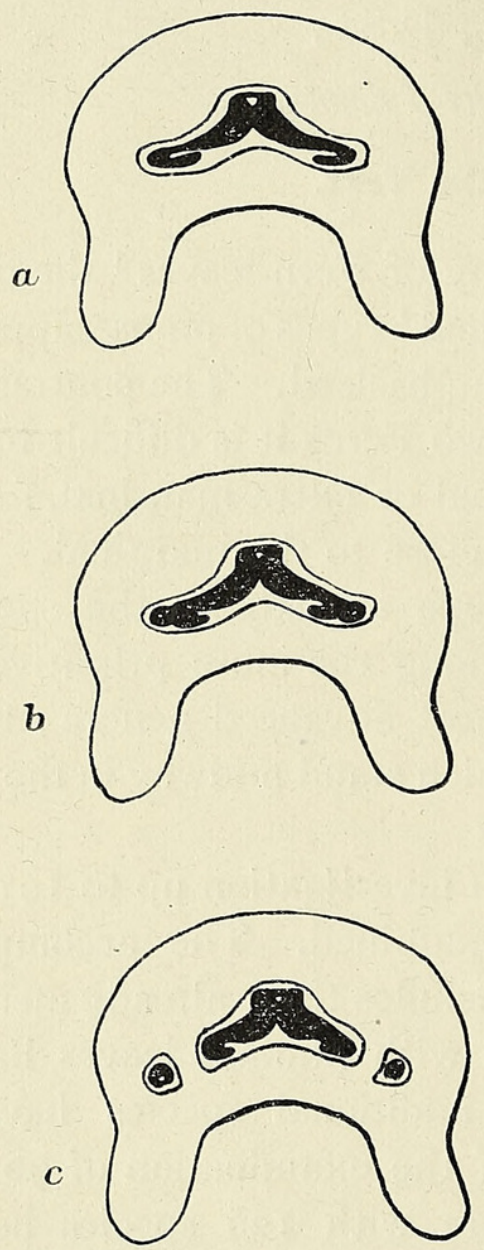

FIG. I. Diagrams showing the development of the extra-marginal type of pinna-supply in Dryopteris vivipara (Raddi), C. Chr.
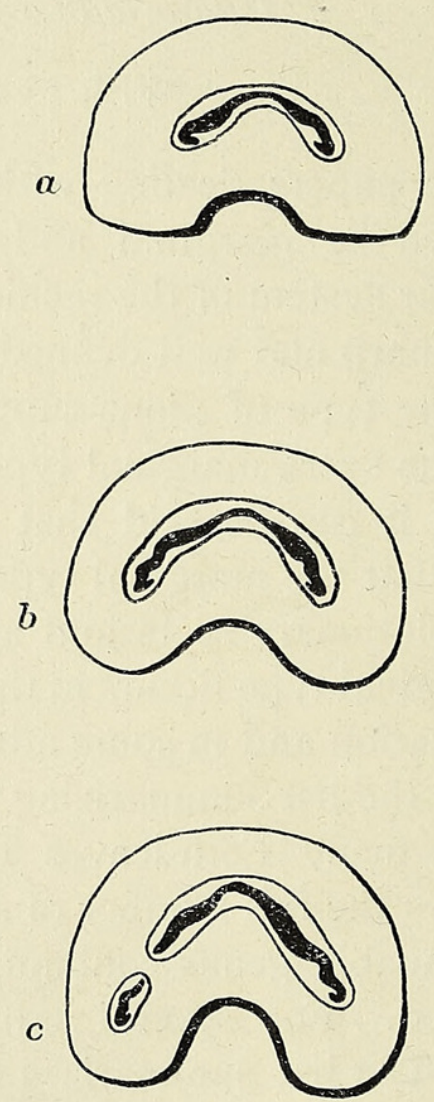

FIG. 2. Diagrams to illustrate the development of the marginal type of pinna-supply in Pteris umbrosa, $\mathrm{R}$. $\mathrm{Br}$.

leaf-trace comes from the back of a hook, we have the 'extra-marginal' type $^{2}$ (Fig. I) ; if it comes directly from the margin (i. e. if the adaxial margin of the leaf-trace is given off), we have the 'marginal' type ${ }^{3}$ (Fig. 2). In either type we may have a portion of the pinna-trace derived from the abaxial side of the leaf-trace. This, a local phenomenon, usually appearing where the pinnae are large, seemed to be the basis of a potential third type

1 Trans. Roy. Soc. Edin., vol. lii, pp. $1-36$.

2 Ann. of Bot., vol. xxvi, p. 250.

\footnotetext{
3 Ibid., p. 25 I.
} 
of pinna-supply (to which I have referred as the 'combination-type'). ${ }^{1}$ There is a combination sometimes of an 'extra-marginal' supply with a 'reinforcement' (Fig. 3); sometimes of a 'marginal' supply with a 'reinforcement' (Fig. 4).

These arrangements appear most prominently among the Cyatheaceae, Aspidieae, and Pterideae. Further investigation of the members of the
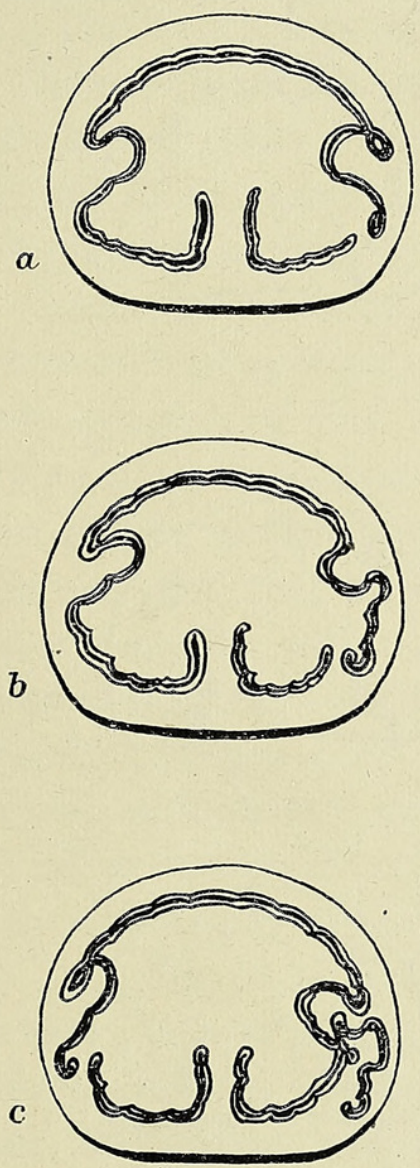

FIG. 3. Diagrams showing the extra-marginal type of pinna-supply, with a 'reinforcement' derived from the abaxial curve of the leaf-trace, in Cibotium barometz (L.), J. Sm.
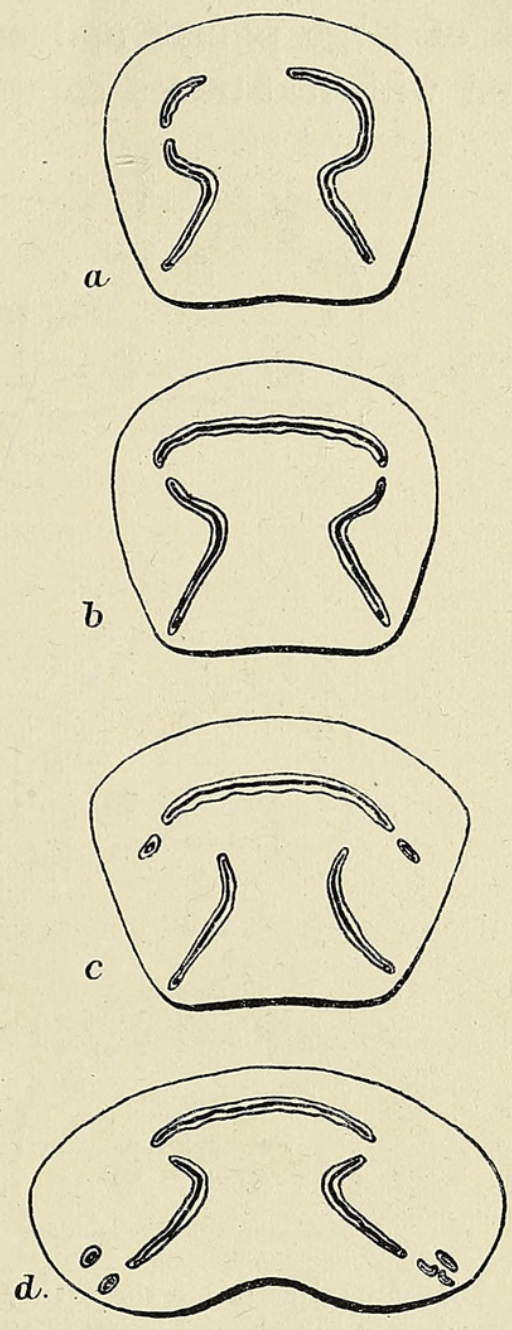

FIG. 4. Diagrams illustrating the marginal type of pinna-supply, with a 'reinforcement' derived from the abaxial curve of the leaf-trace, in Lonchitis pubescens, Willd.

Pterideae, especially of the genera Hypolepis, Paesia, and Pteris, has shown that the appearance of the 'reinforcements' is partly dependent on the size of the leaf. For in Pteris decurrens, Pr., the marginal supply of the pinnae occurs alone in a fairly small leaf, while the marginal supply is reinforced in a leaf with large pinnae. In the genus Paesia, $P$. viscosa, St. Hil., has the marginal supply alone; $P$. scaberula (A. Rich.), Kuhn, possesses a

1 Trans. Roy. Soc. Edin., vol. lii, pp. I2, I4 (cf. ibid., vol, 1, p. 352). 
reinforcement in addition to the marginal supply. In Hypolepis distans (Col.), Hk., the marginal supply appears alone; in $H$. repens (L.), Pr., and $H$. temiifolia (Forst.), Bernh., the marginal supply is reinforced.

The example of Pteris decurrens confirms what has been found in species of the genera Dryopteris, ${ }^{1}$ Polypodium ${ }^{2}$ and Polystichum, ${ }^{3}$ namely, that $a$ 'reinforcement' appears in the pinna-trace where large pinnae are present (Fig. 5). There has been no doubt of the interdependence of the presence of large pinnae and of the appearance of the reinforcement in connexion with leaf-traces composed of several separate vascular strands.


FIG. 5. Diagrams illustrating the extra-marginal type of pinna-supply, with a 'reinforcement' derived from the abaxial curve of the leaf-trace, in Dryopteris grandis (Pr.), C. Chr.

This has already been shown in Polypodium decurrens, Raddi, ${ }^{4}$ and Polystichum adiantiforme (Forst.), J. Sm. ${ }^{5}$ We may now add that, even where the leaf-trace is undivided below the first pinnae, the 'reinforcement' of the part of the pinna-trace derived from the adaxial portion of the leaf-trace is connected with the size of the pinnae.

The occurrence of a 'reinforcement' is not to be regarded as helping to constitute a third type of pinna-supply. The two types of pinna-supply already described are fundamentally contrastive; either type may (usually where large pinnae appear) be reinforced from the abaxial portion of the

1 Trans. Roy. Soc. Edin., vol. lii, p. I I.
Ibid., pp. 7, I 2.
2 Ibid., p. 7

5 Ibid., p. Io.
3 Ibid., p. 10. 
leaf-trace from which it departs. In the list on pp. 242-5 the species in which ' reinforcements' have been found are marked with an asterisk.

The nomenclature used in the list is that adopted by Christensen in the 'Index Filicum'. It has already been stated ${ }^{1}$ that, with a few exceptions, the same type of pinna-supply is found in the species of a genus, recognized as such in the 'Index Filicum'. Compared with the total number of species named in the 'Index Filicum' $(5,940)$, the number I have examined (220) is very small indeed. But it may be pointed out that members of practically every genus with pinnate-leaved species have been examined. The exceptions among the species in my list are found in seven genera. They would be very much more numerous if other systems of nomenclature (e.g. that given in Hooker and Baker's 'Synopsis Filicum') were adopted. Christensen points out in his preface to the 'Index Filicum' that where possible he has adopted the nomenclature of a monographer of a genus. Such a plan has disadvantages as well as very great advantages. For the standards of specific distinction (or even of generic rank) adopted by the monographer of one genus may be, and most frequently are, very different from those of monographers of other genera. It is significant that the greatest degree of agreement between the arrangement of species in the 'Index Filicum' and that based on the constancy of occurrence of the same type of pinna-supply within a genus is found in the genera Dryopteris, Polystichum, and Aspidium, of which Christensen has himself made a special study. Further, it has been found that frequently where plants placed under certain well-known genera like Polypodium or Polystichum have a method of pinna-supply different from that prevalent throughout the genus under which they are placed (e. g. in Hooker and Baker's 'Synopsis Filicum'), they are to be found in the 'Index Filicum' under separate generic names, often in genera with only a few species. For example, the species Phanerophlebia juglandifolia (H. B. Willd.), J. Sm., placed under Polypodium in Hooker and Baker's 'Synopsis Filicum', has the extramarginal type of pinna-supply; in the species of the genus Polypodium recognized in the 'Index Filicum' and enumerated above, the marginal type of pinna-supply prevails. Polystichum viscidulum, C. Chr., has the marginal type of pinna-supply; the extra-marginal type of pinna-supply is found throughout the species of Polystichum I have examined; in the Addenda of the 'Index Filicum' Christensen adopts Maxon's name and puts this species in the genus Adenoderris.

'Turning now to the rule of constancy of type of pinna-supply within a genus of Ferns in the 'Index Filicum', we find the exceptions ${ }^{2}$ in

Balantium stramineum (Labill.), Diels.

Leptochilus tricuspis (Hk.), C. Chr.

1 Trans. Roy. Soc. Edin., vol. lii, p. I5.

2 Judging the condition for the genus from that shown by the majority of species examined. 
Microlepia hirsuta (J. Sm.), Pr.

Odontosoria aculeata (L.), J. Sm.

Odontosoria chinensis (L.), J. Sm., var. Veitchii.

Odontosoria uncinella (Kze.), Fée.

Coniogramme japonica (Thbg.), Diels.

Notholaena marantae (L.), R. Br.

Notholaena sinuata (Lag.), K1f.

Onychium japonicum (Thbg.), Kze.

It is noticeable that none of these species retain the generic names given them when they were first described. In some of the genera the species which have been examined have been named by different authors. This is not the case for all, however, for the three species of Leptochilus in the list on p. 243 have been named by Christensen (whose determinations in the genera Dryopteris, Poiystichum, and Aspidium agree so closely with the grouping based on the type of pinna-supply found in the species), and three out of five of the species of Onychium, including the divergent $O$.japonicum, have been named by Otto Kunze.

In some of the ten species named above, the divergence in the type of pinna-supply is paralleled by divergences in other features. Microlepia hirsuta, for example, has been shown by Professor Bower ${ }^{1}$ to stand aloof from other species of Microlepia in its soral and sporangial characters. Balantium stramineum has been placed in the genera Dicksonia (Labill.), Sitolobium (Brack.), and Dennstaedtia (J. Sm.). In Balantium culcita (L'Hérit.), Klf., and B. coniifolium (Hk.), J. Sm., the marginal type of pinnasupply is found; the extra-marginal type occurs in B. stramineum and in the species examined of Dicksonia, Sitolobium, and Dennstaedtia. Leptochilus tricuspis has the marginal type of pinna-supply; the extra-marginal type is found in other species of the genus. Professor Bower has recently shown ${ }^{2}$ that $L$. tricuspis differs in its 'diplodesmic structure' and in its. 'advanced perforation of the solenostele' from other species of the genus. He separates this species as a member of a monotypic genus, under the name Gymnopteris tricuspis (Hook.), Bedd. Odontosoria aculeata (L.), J. Sm., O. chinensis (L.), J. Sm., var. Veitchï, O. uncinella (Kze.), Fée, were placed with the species of Microlepia by Mettenius in 1856 ; O. bifida (Klf.), J. Sm., O. clavata (L.), J. Sm., O. meifolia (H. B. K.), C. Chr., O. retusa (Cav.), J. Sm., have been placed in various genera, but not in Microlepia. O. aculeata, O. chinensis, var. Veitchii, and $O$. uncinella have, like the species of Microlepia, the extra-marginal type of pinna-supply; the other species have the marginal type. The generic name Coniogramme was proposed by Fée for several species now reduced to C. fraxinea (Don), Diels. C. japonica (Thbg.), Diels, has been variously assigned to Hemionitis (Thbg.), Gymnogramma (Desv.), Dictyogramme ([Pr.], Fée), and Notogramme (Pr.), 
under none of which has $C$. fraxinea been placed. Both species were placed in Gymnogramme (but in different sections of the genus) in Hooker and Baker's 'Synopsis Filicum'. Fée, at the time of proposing the generic name for Coniogramme fraxinea, proposed the name Dictyogramme for Diels' C.japonica. This separation is certainly upheld from the result of examination of the pinna-traces of the two species. Notholaena affinis (Mett.), Moore, N. bonariensis (Willd.), C. Chr., $N$. distans, R. Br., $N$. hirsuta (Poir.), Desv., $N$. hypoleuca, Kze., and $N$. mollis, Kze., have all been placed in the genus Cheilanthes by Mettenius; they agree in having the marginal type of pinna-supply. Notholaena marantae and $N$. simuata, which have the extra-marginal type of pinna-supply, have been placed in various genera, but never in Cheilanthes. In the genus Onychium all four species examined have regularly been grouped together (by Prantl-in Cryptogramme-by Hooker and Baker in the 'Synopsis Filicum', and by Christ in 'Die Farnkräuter der Erde'). There is in this genus no explanation from the nomenclatural data which suggests an isolation of $O$.japonicum from the other species.

In these notes on the 'aberrant' species I by no means wish to suggest a re-grouping based on their types of pinna-supply. The rule regarding the constancy of occurrence of one type of pinna-supply within a genus is not invariably applicable, yet in so large a number of the species examined does it apply, and in several critical genera so closely does a grouping based on the type of pinna-supply correspond with the grouping of species made on other grounds, while so many of the exceptions to the rule have been more or less problematical to systematists, that it would seem that the rule is founded on some real phenomenon and not on mere chance. It is the marked constancy of occurrence of one type of pinnasupply within a genus of Ferns which makes it appear probable that changes in those structural features of a Fern, customarily used for purposes of systematic classification (including generic delimitation), have been accompanied by alterations in the form and system of branching of the leaftrace. These alterations are represented, in part at least, by the abandonment of one type of pinna-supply and the adoption of the other. It was this constancy which led me to use ${ }^{1}$ the attractively concise, if not legitimate, expression, that 'systematic position' is one of 'the factors which control the form of leaf-trace and its system of branching'.

It may be noted that while the marginal or extra-marginal type of pinna-supply has been recorded as characteristic of certain species, the same type of pinna-supply is not found in connexion with every pinna of any Fern-leaf. In many leaves-indeed, in the majority examined-the ultimate pinnae, ${ }^{2}$ and frequently several pairs below the tip of a leaf, ${ }^{3}$ are

1 Trans. Roy. Soc. Edin., vol. lii, pp. 24, 32. 2 Ann. of Bot., vol. xxvi, p. 25 I.

3 Trans. Roy. Soc. Edin., vol. 1, p. 360. 
supplied with their pinna-systems on the marginal plan. But wherever the extra-marginal type of pinna-supply has been found in connexion with any of the pinnae of a leaf, it has also been found that the basal pinnae are supplied extra-marginally. In a paper recently published ${ }^{1}$ from the notes of the late Professor Gwynne-Vaughan, it is remarked that 'it must be remembered that in some species the lowest branches of the rachis and of the primary branches are themselves reduced in size, being markedly smaller than some of those higher up. This reduction affects the method of branching so that it may present features of a more or less primitive type.' In the species which I have examined, several plants have had basal pinnae smaller than those higher up the leaf, but, though there sometimes is a marked reduction in the size of the pinna-trace for these pinnae, compared with that of the pinna-traces of the higher branches, no actual divergence from the type prevalent throughout the lower pinnae has been found. Dr. J. M. Thompson tells me, however, that he has found an irregular occurrence of the extra-marginal type of pinna-supply in leaves of Trismeria trifoliata (L.), Diels-sometimes the extra-marginal type is found, sometimes the marginal. And the one may succeed the other and in turn be succeeded by it as one passes up the leaf from pinna to pinna. In the leaves of Trismeria trifoliata, which I have examined, the extra-marginal type certainly occurs regularly throughout the length of the leaf.

We find, too, that in Ferns which have the extra-marginal type of pinna-supply in the fully mature leaves, the marginal type is regularly found in the earliest leaves. ${ }^{2}$ In order, therefore, to make use of the criterion of the type of pinna-supply, we must examine the lower pinnae of the older leaves of the Ferns we wish to compare.

The results of the investigations detailed in the three earlier papers and in this may now be summarized.

The amount of xylem in the adaxial portion of the leaf-trace is dependent on the situation in which the Fern grows $;^{3}$ the abaxial complications depend on the length of the leaf ${ }^{4}$ the reinforcement of the adaxial strands, on the close crowding together of the pinnae $;^{5}$ the reinforcement of the portion of the pinna-trace derived from the adaxial side of the leaftrace, on the size and complexity of the pinnae. ${ }^{6}$

The presence of adaxial hooks in the leaf-trace seems in great measure to depend on a factor connected with heredity; the hooks may have appeared as Fern-leaves increased in size. ${ }^{7}$

The form of the pinna-trace depends (I) on the presence or absence of hooks in the leaf-trace (an inherited feature-useful, therefore, in phylo-

1 Ann. of Bot., vol. xxx, p. $49 \mathrm{I}$.

3 Ibid., vol. lii, p. 4 .

5 Ibid., pp. 6, 7 .

7 Cf. A. G. Tansley, Ev. of Fil. Vasc. System, p. 1 I 7.
2 Trans. Roy. Soc. Edin., vol. 1, pp. 360, 36r.

4 Ibid., pp. 5, 6, 8, 12.

6 Ibid., pp. $7,9,10 ; 11,13,14$; above, p. 236. 
geny); (2) on the size of the pinnae (a local and individual feature-of practically no value in phylogeny).

The adaxial portion of the pinna-trace is the portion dependent on heredity; the abaxial portion is variable in relation to features of the individual leaf.

The form of the adaxial side of the leaf-trace is connected with the phylogeny of the Fern in which it occurs; its outline and relations are useful as phylogenetic criteria. The form of the abaxial portion is dependent upon individual peculiarities, ${ }^{1}$ and is therefore of little value in phylogenetic criticism.

The way in which the adaxial part of the leaf-trace gives off part (or all) of the pinna-trace is important, as that part of the leaf-trace alters its form apparently in response to phylogenetic influences. The actual shape of the pinna-trace is of little importance, but the method of development of the portion of it which comes from the adaxial side of the leaf-trace appears likely to be a useful addition to the criteria of value in the study of the phylogeny of the Ferns.

\section{SUMMARY.}

I. There are two types of pinna-supply from the leaf-trace in the Ferns. In the 'extra-marginal' type, the portion of the pinna-trace which comes from the adaxial side of the leaf-trace is nipped off from the back of a 'hook', technically from the abaxial face of the curved leaf-trace; the extreme tip of the adaxial portion of the leaf-trace is continued upward as part of the leaf-trace. In the 'marginal' type, the adaxial portion of the leaf-trace (nearest to the pinna) is itself given off to supply the pinna. In both types (usually in connexion with large pinnae) a portion of the pinnatrace may be derived from the abaxial side of the leaf-trace.

2. A tabular scheme of the distribution of the two types of pinnasupply in the Ferns has been drawn up; among the Ferns examined, the extra-marginal type occurs in 46 genera with 94 species, the marginal type is found in $5 \mathrm{I}$ genera with $\mathrm{I} 26$ species.

3. With a few exceptions (seven genera), the rule holds that the same type of pinna-supply is found in the species of a genus of Ferns recognized as such in Christensen's 'Index Filicum'. Even in the exceptions, there is considerable agreement between the grouping of the species according to

1 Among entire-leaved species of the genus Polypodium there have been examined $P$. vaccinifolium, Langsd. et Fisch.; $P$. lycopodisides, Linn.; P. percussum, Cav.; $P$. pustulatum, Forst.; P. glaucophyllum, Kze.; P. Xiphias (Moore), Bak.; P. lingua, Vahl ; P. crassifolium, Linn.; and $P$. punctatum (L.), Sw. In $P$. vaccinifolium, $P$. lycopodioides, and $P$. percussum the leaf is short ; only one or two strands regularly occur in the leaf-trace. In $P$. pustulatum, P. glaucophyllum, $P$. Xiphias, and $P$. lingua the leaves are longer; strands appear on the abaxial side of the leaf-trace, in addition to the adaxial pair. In $P$. crassifolium and $P$. punctatum, which have leaves longer than those of any of the preceding species, there is a strongly developed abaxial system of many strands. 
the type of pinna-supply found in them and that made on other grounds by some systematists.

4. In order to make use of the criterion of the type of pinna-supply in the Ferns, the lower pinnae of the older leaves must be examined.

Family.

Osmundaceae

Hymenophyllaceae

Dicksonieae

Thyrsopterideae

Cyatheae

Woodsieae

(Woodsiinae)
Marginal Type of Pinna-supply.

Extra-marginal Type of Pinna-supply.

Todea barbara (L.), Moore.

Leptopteris Fraseri (Hk. and Grev.), Pr. ;

L. hymenophylloidies (A. Rich.), Pr.

Osmunda javanica, Bl. ;

O. regalis, L.

Schizaeaceae

Gleicheniaceae

Lygodium circinnatum (Burm.), Sw.;

L. scandens (L.), Sw.

Mohria caffrorum (L.), Desv.

Aneimia collina, Raddi ;

A. hirta (L.), Sw.;

A. phyllitidis (L.), Sw. ;

A. rotundifolia, Schrad.

Gleichenia circinnata, Sw., var. speluncae:

G. flabellata, R. Br.;

$G$. mpestris, R. Br.

Loxsoma Cumningliami, $\mathrm{R} . \mathrm{Br}$.

Hymenophyllum demissum (Forst.), Sw. ;

11. dilatatum (Forst.), Sw.

Trichomanes elegans, Rich.;

$T$. radicans, Sw.

Balantium culcita (L'Hérit.), Klf. ; Balantium stramineum (Labill.), $B$. coniifolium (Hk.), J. Sm.

\section{Diels.}

Dicksonia antarctica, Lab. ;

D. fibrosa, Col. ${ }^{1}$

*Cibotium barometz (L.), J. Sm. ; ${ }^{2}$

C. regale, Linden;

C. Schiedei, Schlecht. et Cham.

C. Wendlandi, Mett., var. Vershaffeltii.

* Thyrsopteris elegans, Kze.

* Cyathea mexicana, Schlecht. et Cham.;

*C. pubescens, Mett.

* Hemitelia grandifolia (Willd.), Spr.

*Alsophila glauca (Bl.), J. Sm.

Cystopteris fragilis (L.), Bernh. ;

C. montana (Lam.). Bernh.

* Hypoderris heteroneuroides, Christ.
Diacalpe aspidioides, $\mathrm{Bl}$.

Peranema cyatheoides, Don.

Woodsia ilvensis (L.), R. Br. ;

$W$. polystichoides, Eat.

Acrophorus stipellatus (Wall.),

Moore.

1 In Trans. Roy. Soc. Edin., vol. 1, p. 354, this species was described as having the marginal type of pinna-supply. The identification of the material then examined must have been incorrect. l'roperly authenticated material since examined shows this species to have the extra-marginal type of pinna-supply.

2 The species marked with an asterisk are those in which 'reinforcements' have been found (see pp. 236, 237). 
Family.

(Onocleineae)

Aspidieae (Aspidiinae)
Marginal Type of Pinna-supply.
Extra-marginal Type of Pinna-supply.

Mattencia orientalis (Hk.), Trev. ; $M$. struthiopteris (L.), Todaro. Onoclea sensibilis, L.

Dryopteris filix-mas (L.), Schott ;

*D. grandis (Pr.), C. Chr.;

D. phegopteris (L.), C. Chr.;

D. pulvinulifera (Bedd.), O. Ktze. ;

D. serrata (Cav.), C. Chr. ;

D. setigera (Bl.), O. Ktze. ;

D. vivipara (Raddi), C. Chr.

Polybotrya cervina (L.), Klf.

* Leptochilus tricuspis (Hk.), C. Chr.

Mesochlaena polycarpa (Bl.), Bedd.

Didymochlaena truncatula (Sw.),

J. Sm.

Cyclopeltis semicordata (Sw.), J. Sm.

Polystichum aculeatum (L.), Schott, var. angulare, $\mathrm{Pr}$. ;

* $P$. adiantiforme (Forst.), J. Sm. ;

P. falcatum (L. fil.), Diels ;

P. Hookerianum (Pr.), C. Chr.;

P. Standishii (Moore), C. Chr.;

$P$. vestitum (Forst.), Pr.

Phanerophlebia juglandifolia, (H. B. Willd.), J. Sm.

Plecosorus speciosissimus (A. Br.), Moore.

* Leptochilus cuspidatus (Pr.), C. Chr.;

* L. guianensis (Aublet), C. Chr.

Leptolepia novae-zelandiae (Col.),

Davallia assamica (Bedd.), Bak.;

D. bullata, Wall.;

D. dissecta, J. Sm. ;

D. immersa, Wall.;

D. pallida, Mett.;

D. pentaphylla, Bl. ;

$D$. solida (Forst.), Sw.;

D. solida, var. fijiensis.

Arthropteris altescandens (Colla), J. Sm.

Nephrolepis Amerpohlii, hort. ;

N. Fosteri, hort., Hill ;

N. Piersoni, hort.;

N. Scottii, hort.

Humata botrychioides, Brack. ;

H. repens (L. fil.), Diels, var. alpina ; Kuhn.

Microlepia hirta (Klf.), Pr.;

$M$. hirta, var. cristata;

M. platyphylla (Don), J. Sm.;

M. speluncae (L.), Moore ;

$M$. strigosa (Thbg.), $\mathrm{Pr}$.

Odontosoria aculeala (L.), J. Sm. ;

O. chinensis (L.), J. Sm., var.

Veitchii;

O. uncinella (Kze.), Fée.

Dennstaedtia adiantoides (H. B. Willd.), Moore.

Monachosoram subdigitatum ( $\left.\mathrm{Sw}_{0}\right)$, J. Sm.

$H$. vestita (Bl.), Moore ;

* Saccoloma domingense (Spr.), Prantl ;

$S$ Imrayanum, Hook.

Diellia falcata, Brack.;

D. pumila, Brack.

Microlepia hirsuta (J. Sm.), Pr.

Lindsaya repens (Bory), Bedd.;

L. stricta (Sw.), Dry.

Odontosoria bifida (Klf.), J. Sm. ;

O. clavata (L.), J. Sm. ;

O. meifolia (H. B. K.), C. Chr. ;

O. retusa (Cav.), J.Sm.

Tapeinidium Denhami (Hk.), C. Chr.;

T.pinnatum (Cav.), C. Chr.

Schizoloma ensifolium (Sw.), J. Sm. 
Family.

Asplenieae (Aspleniinae)

(Blechninae)

Pterideae (Gymnogramminae)

(Cheilanthinae)
Marginal Type of Pinna-supply.

Asplenium adiantum nigrum, L.; A. bulbiferum, Forst., var. Fabianum ;

A. bulbiferum, var. Hillii;

A. Finlaysonianum, Wall.;

A. obtusatum, Forst. ;

A. pinnatifidum, Nutt.;

A. praemorsum, $\mathrm{Sw}$. ;

A. ruta muraria, L. ;

A. tenerum, Forst.;

A. trichomanes, L.

Ceterach aureum (Cav.), L. v. Buch.;

C. Dalhousiae (Hk.), C. Chr.;

C. officinarum, DC.
Extra-marginal Type of Pinna-supply.

Athyrium filix foemina (L.), Roth ; $A$. alpestre (Hoppe), Rylands. Diplazium celtidifolium, Kze. ; D. marginatum (L.), Diels ; D. Shepherdii (Spr.), Link. Diplaziopsis javanica (Bl.), C. Chr.
Blechnum attenuatum (Sw.), Mett. ;

B. Banksii (Hk. fil.), Mett. ;

$B$. brasiliense, Desv. ;

$B$. capense (L.), Schlecht. ;

$B$. discolor (Forst.), Keys. ;

B. lanceolatum (R. Br.), Sturm.;

B. Moorei, C. Chr.;

$B$. occidentale, Mett. ;

$B$. orientale, L.;

B. Patersoni (R. Br.), Mett. :

B. punctulatum, Sw., var. Krebsii, Kze. ;

B. spicant (L.), Wither, ;

$B$. tabulare (Thbg.), Kuhn.

* Sadleria cyatheoides, Klf.

Brainea insignis (Hk.), J. Sm.

* Stenochlaena sorbifolia (L.), J. Sm.

Woodwardia radicans (L.), Sm.

Doodia aspera, R. Br., var. multifida.

Anogramma leptophylla (L.), Link.

Gymnogramma Pearcei, Moore, var. robusta.

Coniogramme fraxinea (Don), Diels. Gymnopteris tomentosa (Lam.), Und.

Ceropteris calomelanos (L.), Und. ;

C. calomelanos, var. chrysophylla, Klf.

Pellaea auriculata (Thbg.), Fée ;

P. hastata (Thbg.), Prantl;

P. nivea (Poir.), Prantl ;

$P$. rotundifolia (Forst.), $\mathrm{Hk}$.

Notholaena affinis (Mett.), Moore;

$N$. bonariensis (Willd.), C. Chr. ;

N. distans, R. Br.;

$N$. hirsuta (Poir.), Desv. ;

$N$. hypoleuca, Kze.;

$N$. mollis, Kze.

Cheilanthes argentea (Gmel.), Kze. ;

C. myriophylla, Desv., var. elegans.

Hypolepis distans (Col.), Hk.;

*H.repens (L.), $\mathrm{Pr}$.;

*H. tenuifolia (Forst.), Bernh.

Llavea cordifolia, Lag.

Onychium melanolepis (Dene.), Kze.; Onychium japonicum (Thbg.), Kze.

O. siliculosum (Desv.), C. Chr.;

O. strictum, Kze.

Cryptogramma crispa (L.), R. Br.;

C. Stelleri (Gmel.), Prantl.

Plagiogyria glanca (Bl.), Mett.
Coniogramme japonica (Thbg.), Diels.

Trismeria trifoliata (L.), Diels.

Notholaena Marantae (L.), R. Br.; N. sinuata (Lag.), KIf. 
Family.

(Adiantinae)

(Pteridinae)

Polypodieae

(Taenitidinae)

(Polypodiinae)

Acrosticheae

(Acrostichinae)

\section{Marginal Type of Pinna-supply.}

Extra-marginal Type of Pinna-supply.

Adiantum polyphyllum, Willd.; $A$. sanctae Catharinae, hort., J. Sm.

Actiniopteris australis (L. fil.), Link. Anopteris hexagona (L), C. Chr.

* Ochropteris pallens (Sw.), J. Sm.

Pteris atrovirens, Willd.;

$P$. biaurita, L. ;

P. cretica, L. ;

$P$. decurrens, $\mathrm{Pr}$.;

P. macilenta, A. Rich.;

*P. podophylla, Sw. ;

P. tremula, R. Br.;

P. umbrosa, R. Br.

* Histiopteris incisa (Thbg.), J. Sm.

* Pteridium aquilinum (L.), Kuhn.

* Paesia scaberula (A. Rich.), Kuhn; P. viscosa, St. Hil.

Lonchitis hirsuta, L. ;

*L. pubescens, Willd.

Taenitis blechnoides (Willd.), Sw.

Polypodium aureum, L. ;

$P$. brasiliense, Poir.;

$P$. Catharinae, Langsd. et Fisch.:

$P$. cultratum, Willd.;

*P. decurrens, Raddi ;

$P$. ellipticum, Thbg.;

$* P$. Fendleri, Eat. ;

$P$. lepidopteris (Langsd. et Fisch.),

Kze. ;

$P$. loriceum, L.

P. phymatodes, L.;

$P$. plumula, H. B. Willd. ;

$P$. polypodioides (L.), Hitchcock;

P. Schneideri, hort., Veitch ;

$P$. serrulatum (Sw.), Mett.;

$P$. vulgare, L.

Dryostachyum drynarioides (Hk.), Kuhn.

Drynaria rigidula (Sw.), Bedd.

Trachypteris pinnata (Hk. fil.), C. Chr. (fertile leaf). 


\section{$2 \mathrm{BHL}$ Biodiversity Heritage Library}

Davie, R. C. 1918. "A comparative list of fern pinna-traces, with some notes on the leaf-trace in the ferns." Annals of botany 32, 233-245.

https://doi.org/10.1093/oxfordjournals.aob.a089673.

View This Item Online: https://www.biodiversitylibrary.org/item/238284

DOI: https://doi.org/10.1093/oxfordjournals.aob.a089673

Permalink: https://www.biodiversitylibrary.org/partpdf/320216

\section{Holding Institution}

Smithsonian Libraries

\section{Sponsored by}

Biodiversity Heritage Library

\section{Copyright \& Reuse}

Copyright Status: Not in copyright. The BHL knows of no copyright restrictions on this item.

This document was created from content at the Biodiversity Heritage Library, the world's largest open access digital library for biodiversity literature and archives. Visit BHL at https://www.biodiversitylibrary.org. 